\title{
Emílio Goeldi e o Museu Paraense: em busca do conhecimento sobre a natureza amazônica
}

\author{
Emilio Goeldi and the Paraense Museum: in quest of \\ an understanding of nature in the Amazon
}

\author{
Luciana Rossato \\ Professora da Universidade Estadual de Santa Catarina. Doutora em história pela \\ Universidade Federal do Rio Grande do Sul. \\ lucianarossato@yahoo.com.br
}

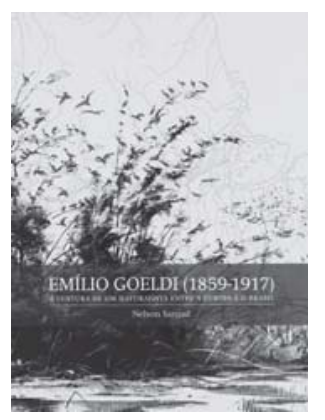

SANJAD, Nelson. Emílio Goeldi (1859-1917): a ventura de um naturalista entre a Europa e o Brasil. Versão para o francês, Janine Houard. Rio de Janeiro: EMC, 2009, 232p., il.

\begin{abstract}
$\mathrm{A}$ o escrever a biografia do zoólogo suíço Emílio Goeldi, Nelson Sanjad focou principalmente o período em que o naturalista viveu no Brasil, entre os anos de 1884 e 1907, inicialmente no Rio de Janeiro e posteriormente em Belém do Pará. Durante esse período Goeldi desenvolveu vários estudos científicos, mas tornou-se nacional e mundialmente conhecido pelo seu trabalho à frente do Museu Paraense (atual Museu Paraense Emílio Goeldi), onde conseguiu conciliar rigor científico e sucesso de público. O livro, no entanto, não é apenas uma biografia do naturalista. É também uma viagem que passa pelo complexo campo dos estudos científicos no Brasil no final do século XIX e início do XX, pelas relações estabelecidas entre órgãos científicos brasileiros e seus congêneres europeus e pelas contribuições de cientistas europeus para o conhecimento da natureza brasileira e amazônica.
\end{abstract}

O autor é doutor em história das ciências e da saúde pela Fundação Oswaldo Cruz. Atualmente é coordenador de Comunicação e Extensão do Museu Paraense Emílio Goeldi/MCT e professor do Centro Universitário do Pará. Realizou extensa pesquisa nos documentos e textos produzidos por Emílio Goeldi, que incluem livros, álbuns, anais e inúmeros artigos publicados em periódicos científicos, revistas e jornais, tanto na Europa como no Brasil. Seu estudo se insere numa vertente das pesquisas históricas que foi retomada recentemente: a biografia. Na década de 1980 houve uma revalorização dos estudos biográficos na França, não com o mesmo objetivo dos historiadores positivistas, que era de resgatar a história dos 'grandes homens', mas com a visão de que, a partir da vida dos indivíduos, testemunhas privilegiadas de seu tempo, é possível explicar aspectos do passado. Segundo Kalina Vanderlei Silva "os historiadores optam por uma abordagem em que, por meio da história de vida do retratado, é possível visualizar traços característicos do período histórico em que o mesmo viveu" (2009, p.16).

O subtítulo da obra nos remete a ambiguidade da imagem dos indivíduos que se dedicavam à ciência no século XIX: a ventura ou aventura? O autor escolheu a ventura. 
Teria sido pelo duplo significado: fortuna, prosperidade, boa sorte, mas também risco, perigo? Não sabemos, também pode ser aventura. Ser viajante e cientista no século XIX e no início do XX era ter que, como Goeldi, enveredar por regiões inóspitas atrás de novos espécimes. Era ter que deixar a Europa e aventurar-se por outros continentes e países. Para os conterrâneos e colegas desses cientistas, as viagens por terras distantes e pouco conhecidas, sejam elas de poucos meses ou de anos, eram percebidas como uma aventura. Nos elogios dirigidos a esses estudiosos salientavam-se características como coragem, zelo e abnegação em nome da ciência. Alguns biógrafos vão mais além e reforçam a imagem heroicoromântica dos viajantes.

Como nos mostra Sanjad, na segunda metade do século XIX as instituições científicas européias eram altamente profissionalizadas e os poucos postos de trabalho eram muito disputados, o que gerava conflitos, forçando cientistas jovens e talentosos a buscar em outros países, entre eles os da América Latina, espaço para desenvolverem seu potencial.

A obra está dividida em duas partes: na primeira, intitulada "Itinerário de Viagem", o autor descreve a vida de Emílio Goeldi, sua formação na Europa, a vinda para o Brasil, sua vida no Rio de Janeiro e em Belém do Pará, o trabalho que desenvolveu no Museu Nacional e no Museu Paraense e, por fim, o retorno à Suíça, onde veio a falecer em 1917, aos 57 anos de idade. Na segunda parte, intitulada "Percurso Intelectual", Sanjad faz um mapeamento da produção intelectual de Goeldi, discutindo-a a luz do contexto em que foi produzida, bem como as áreas de interesse as quais se dedicou.

Com 25 anos, solteiro e tendo defendido sua tese na Universidade de Jena, Emílio Goeldi é convidado para trabalhar na seção zoológica do Museu Nacional. Seis anos depois, em 1891, já casado, estabeleceu-se na Colônia Alpina (empreendimento financiado pelo sogro), na qual tinha a função de diretor. Apesar do fracasso do projeto de imigração, os anos na colônia não foram improdutivos, uma vez que Goeldi aproveitou para aumentar sua coleção particular de espécimes animais e vegetais e desenvolver estudos sobre a natureza na serra dos Órgãos, o que resultou em vários artigos sobre a fauna da Mata Atlântica. Em 1894, a convite do governador do Pará, torna-se diretor do Museu Paraense, o qual, sob sua direção, passou por uma reforma administrativa, com mudança e ampliação da sede e construção de um zoológico e de um horto. No entanto, o mais importante foi a definição de um programa regional que estabeleceu as diretrizes das atividades a serem desenvolvidas pelo Museu Paraense. Na impossibilidade de competir com os grandes museus, Goeldi "propôs a criação de um instituto especializado nas questões amazônicas, ciente de que na região havia trabalho de sobra para um naturalista e de que a natureza local iria atrair o interesse da comunidade científica internacional" (Sanjad, 2009, p.42).

Em nome da ciência foram desapropriados terrenos e expulsos proprietários e pequenos agricultores vizinhos ao Museu, que eram um empecilho às obras necessárias a ampliação e desenvolvimento das atividades da instituição. Com o apoio do governo paraense, o diretor promoveu a transformação do espaço, inspirando-se na estética européia. O horto botânico e o jardim zoológico tinham traçados e elementos arquitetônicos que remetiam a Europa. Sob a direção de Goeldi, o Museu tornou-se uma 'colônia científica' de inspiração européia: os funcionários (inclusive Goeldi e a família) residiam nas dependências do Museu Paraense; as construções eram em estilo enxaimel; lagos tinham a forma do lago 
Maggiore e do mar Negro e a torre de observações astronômicas e meteorológicas era uma cópia da torre Eiffel. Como salienta Sanjad, "ali apenas plantas e animais eram amazônicos; o restante, Europa transplantada" (Sanjad, 2009, p.46). Além disso, jovens pesquisadores europeus foram convidados para trabalhar na instituição. Goeldi foi muito hábil e conseguiu manter o Museu Paraense protegido das instabilidades políticas do início da República ao criar uma Sociedade Zeladora (da qual faziam parte indivíduos influentes da sociedade paranaense) e ao transformar o museu, com seu horto botânico e jardim zoológico, em "não apenas um lugar de ciência, mas também de curiosidade, de instrução, de passatempo, de turismo, de adultos e crianças, de letrados e analfabetos" (Sanjad, 2009, p.56).

Goeldi teve uma produção extensa, publicou livros, artigos em periódicos nacionais e estrangeiros e traduziu obras para o português. Sua trajetória profissional deu-se a partir de interesses pessoais, contingências e oportunidades que surgiram no decorrer da vida. Segundo Sanjad sua obra foi produzida em regiões de fronteira: "fronteiras entre Europa e Brasil; entre ciência, história e divulgação; entre ciência e ciência aplicada; entre tradições científicas do século XIX e do século XX" (2009, p.93).

À frente do Museu Paraense, Emílio Goeldi concentrou seus esforços na ampliação dos conhecimentos sobre a fauna amazônica. Além disso, dedicou-se a estudos em várias áreas, como história da ciência, evolucionismo e zoologia aplicada voltada a entomologia e a ecologia, com o fim de prover as demandas estatais no combate as epidemias, principalmente a febre amarela. Goeldi também empreendeu esforços no campo da divulgação científica. À frente do Museu organizou exposições e palestras com o "objetivo de educar o olhar e o pensamento da população, valorizando um campo social que avançava de maneira extraordinária no século XIX, o da ciência e da técnica" (Sanjad, 2009, p.138). Emílio Goeldi foi um homem da ciência do final do século XIX, ou seja, acreditava no poder dessa ciência, dedicava-se às pesquisas e estava engajado na divulgação do conhecimento, com o objetivo de formar e educar a população em geral.

Em seu estudo sobre Emílio Goeldi, Nelson Sanjad nos possibilita, além de acompanhar a trajetória de um naturalista europeu no Brasil, conhecer um pouco da história dos estudos científicos sobre a natureza da Amazônia no final do século XIX e início do XX, bem como as complexas relações entre a ciência e a política. Em tempos de leitores cada vez mais ligados às novas tecnologias, a editoração caprichada, com fotos de época e imagens e documentos produzidos pelo naturalista e por seus colegas de oficio, encanta o leitor e complementa o texto de leitura ao mesmo tempo densa e agradável.

\section{REFERÊNCIAS}

FREITAS, Marcus Vinícius de.

Charles Frederick Hartt: um naturalista no império de Pedro II. Belo Horizonte: EdUFMG, 2002.
SILVA, Kalina Vanderlei; SILVA, Maciel

Henrique.

Dicionário de conceitos históricos. São Paulo: Contexto. 2009. 